$\begin{array}{ll}\text { Abstracta Iranica } & \begin{array}{l}\text { Abstracta Iranica } \\ \text { Revue bibliographique pour le domaine irano-aryen }\end{array} \\ & \text { Volume } \mathbf{3 4 - 3 5 - 3 6 | 2 0 1 7} \\ \text { Comptes rendus des publications de 201 1-2013 }\end{array}$

\title{
Elisa Gagliardi Mangilli (ed.). I doni di Shah Abbas il Grande alla Serenissima. Relazioni diplomatiche tra la Repubblica di Venezia e la Persia Safavide
}

\section{Iván Szántó}

\section{(2) OpenEdition}

Electronic version

URL: http://journals.openedition.org/abstractairanica/42198

DOI: 10.4000/abstractairanica.42198

ISSN: 1961-960X

Publisher:

CNRS (UMR 7528 Mondes iraniens et indiens), Éditions de l'IFRI

\section{Electronic reference}

Iván Szántó, «Elisa Gagliardi Mangilli (ed.). I doni di Shah Abbas il Grande alla Serenissima. Relazioni diplomatiche tra la Repubblica di Venezia e la Persia Safavide », Abstracta Iranica [Online], Volume 34-35-36 | 2017, document 19, Online since 30 July 2017, connection on 02 October 2020. URL http://journals.openedition.org/abstractairanica/42198; DOI : https://doi.org/10.4000/ abstractairanica. 42198

This text was automatically generated on 2 October 2020 .

Tous droits réservés 


\title{
Elisa Gagliardi Mangilli (ed.). I doni di Shah Abbas il Grande alla Serenissima. Relazioni diplomatiche tra la Repubblica di Venezia e la Persia Safavide
}

\author{
Iván Szántó
}

\section{REFERENCES}

Elisa Gagliardi Mangilli (ed.). I doni di Shah Abbas il Grande alla Serenissima. Relazioni diplomatiche tra la Repubblica di Venezia e la Persia Safavide. Catalogue of an exhibition, held at the Palazzo Ducale in Venice, 28 September 2013-12 January 2014, Venice, 2013, $79 \mathrm{p}$.

The volume has been published to accompany an exhibition, supervised by the Civic Museums Fund of Venice (Fondazione Musei Civici di Venezia). This display can be regarded as a focused follow-up of the Venice and the Islamic World, 828-1797 exhibition (Paris, 2006; New York, 2007), since it covers Safavid Persia and its Venetian archival records, i.e., subjects which were largely left unexplored by its predecessor. It also compares well with a British Museum exhibition, entitled "Shah 'Abbas: the Remaking of Iran" (2009), which, however, concentrated mostly on Iran's internal affairs. Boasting, in its Sala delle Quattro Porte, a monumental (over $5 \mathrm{~m}$ long) canvas, known as the Doge Marino Grimani receiving gifts from the Persian ambassadors (1604), there is hardly any better location in Venice than the Doge's Palace for a survey of Shah 'Abbas I's Venetian interests and a display of the vestiges of Veneto-Safavid diplomatic contacts. Both the volume and the exhibition revolves around this exceptional painting, the ascription of which in the volume by Camillo Tonini to 
Gabriele Caliari being not consensual in scholarship (see G. Rota: " Safavid Envoys in Venice ", in: Ralph Kauz et al., eds., Diplomatisches Zeremoniell in Europa und im Mittleren Osten in der frühen Neuzeit. Vienna, 2009, p. 229, n. 46). This unique reception scene encapsulates in a single moment more than two centuries of intense exchanges between the Serenissima and the Safavids: during these two hundred years, including the heightened diplomatic hustle and bustle of Shah 'Abbas I's reign, no comparable representation was made and no such lavish audience was accorded to any Persian envoy other than Fathī Bayg whose arrival the painting commemorates.

The small volume consists of eight richly illustrated articles. Two contributions by the editor of the volume investigate what the author has dubbed as the "Small Game" (contrasting the subsequent Russo-British "Great Game" for hegemony over Asia), i.e., diplomatic and trade ventures between the shah and the doge aiming to outplay the Ottomans; attention is also drawn to the special role of the Armenian diaspora in this procedure, as well as the surviving luxury items, among them silk fabrics and carpets. The Venetian perception of Persia and the Persians is the subject of articles by Giampiero Bellingeri and Diana Cristante, from a moral and strategical standpoint on the one hand, and a topographical perspective (as shown by maps) on the other. An essay by Alessandra Schiavon deals with the archival records of Veneto-Persian diplomatic contacts, including the removal and eventual restitution of the documents after the end of the Republic of Venice, and highlights the original farmān of Shah 'Abbās I, presented to Doge Marino Grimani by Fathī Bayg; alongside this document its contemporary Venetian transcription and translation, handwritten by a dragoman, are also published. The concluding study, by Cristina Crisafulli, analyses the monetary dimension of art in early 17th century Venice.

While the catalogue does not substitute for the standard reference works on Safavid historical epistles (e.g. Lajos Fekete, Einführung in die persische Paläographie, Budapest, 1977) or the Iranian policy of the Serenissima (e.g. Giorgio Rota, Under two Lions. On the Knowledge of Iran in the Republic of Venice, ca. 1450-1797, Vienna, 2009), it makes this colourful chapter of Early Modern Eurasian diplomacy more accessible to the public, while introducing hitherto unpublished documents and artifacts and providing new insights into the subject.

\section{AUTHORS}

\section{IVÁN SZÁNTÓ}

Eötvös Loránd University, Budapest 